\title{
About the Impact of The Concept Of E- Government on Modern Education in Russia
}

\author{
Vladimir Olegovich Mikryukov ${ }^{1 *}$, Sergey Anatolevich Melkov², Artur Sergeevich \\ Sushanskiy $^{3}$, Ivan Vladimirovich Kholikov ${ }^{4}$, and Nadezhda Vsevolodovna Gruver ${ }^{4}$ \\ ${ }^{1}$ Financial University Under the Government of The Russian Federation, Department of Sociology, \\ History and Philosophy, Moscow, Russia \\ ${ }^{2}$ Academy of Civil Defense of the Ministry of Emergency Situations of Russia, Department of State \\ and Municipal Management, Moscow, Russia \\ ${ }^{3}$ Financial and Industrial University Synergy, Department of State and Municipal Management, \\ Moscow, Russia \\ ${ }^{4}$ Institute of Legislation and Comparative Law under the Government of the Russian Federation, \\ Department of International and European Law, Moscow, Russia
}

\begin{abstract}
The hermeneutics of the concept of "e-government" is implemented, and the results are interpreted in the article using the method of expert survey. The goal of the study was to find out the relation between the digitalization of public administration in modern Russia and higher education. The conclusions on the impact of the concept of e-government on Russian education have been drawn, based on the interpretation of the experts' answers. Some conclusions from a pedagogical experiment conducted on an ongoing basis at the Academy of Civil Defense of the Ministry of the Russian Federation for Civil Defense, Emergencies and Elimination of Consequences of Natural Disasters since 2016 have been also provided in the article. The goal of this experiment is to find out which pedagogical and information technologies are the most efficient for teaching at a university. The authors are confident that the problems of the mutual influence of the e-government and modern education in Russia described in the article are inexhaustible and will be continued by them.
\end{abstract}

\section{Introduction}

Even before the coronavirus pandemic of 2020, it became clear that the Russian education system and the applied educational methods and technologies were being increasingly virtualized several years ago.

The authors only update some results of the pedagogical experiment conducted at the Academy of Civil Defense of the Ministry of the Russian Federation for Civil Defense, Emergencies and Elimination of Consequences of Natural Disasters in 2016 in this article: "... the use of distance learning technologies (hereinafter referred to as DLT) allows most students to successfully solve the proposed educational tests. Moreover, the success of the solution seems to be inversely dependent on the number of class hours (less hours means that

* Corresponding author: mikryukov.v.o@gmail.com 
more time is spent on solving tests) and directly dependent on the use of DLT (more DLT means that more time is spent on solving tests)" [1]. The authors clarify that the results of the experiment are not reduced only to this conclusion.

The authors consider it obvious that digitalization, which has impact on the people's lives, politics, and governance in Russia, will completely change both the educational system and the relations between teachers and students.

\section{Relevance of the problem}

Continuing the update, the authors note that there are no doubts in the further digitalization and virtualization of the domestic system of state and municipal government and their objective impact on the educational system. However, this raises several complex questions. For example, if the concept of the Open Government as the eponymous ministry in Russia has not yet been established, does this mean the actual "death" of this project? Another complex question is whether the e-government can be a monopoly (accordingly, whether there can be a monopoly educational system in the e-government), or the government digitalization inevitably entails the democratization of public relations in any sector of public life and actually involves civil society institutions in the management of society.

There are many questions of this kind. Most of them have not yet been answered in practical terms. The problem of this study is the answer to the question of how realistic it is to form an efficient e-government in Russia using the project management methods. The authors make an attempt to understand the idea and specifics of the e-government first.

\section{Authors' analysis of the problem}

Researchers in Russia and other countries actively explore the development of the egovernment and the establishment of modern education. They include such Russian scientists as V.Yu. Panchenko, R.A. Romashov [2], A.F. Darmilov, M.B. Ponyavina [3], D.O. Giordano, M.B. Ponyavina [4] and others, as well as foreign experts: V.H. Kremen [5], Z. Huang, M. Semwal, W.S. Tan, R. Bajpai, W. Ong, S.Y. Lee, Tee M., L. Tudor Car [6], G. Weichhart, C. Stary, M. Appel [7], X. Wang [8], A. Hariharasudan, S. Kot [9] and others. Given the complexity of the scientific problem, it was decided to conduct an expert survey on theoretical and methodological definitions and processes that described the formation of the e-government in Russia. To do this, the experts had to select one of the five ratings (horizontal) in the table below and put any mark (cross, circle, tick, any number, etc.) in the corresponding field. The experts could express their opinion of any size in the right column of the table, if desired. There was no need to indicate the last name, because it was planned to process the results in a generalized form and then present them in the scientific space as a scientific article. $N=15$. The teachers from four universities in Moscow and the Moscow region were selected as the experts. The results are provided in Table 1. 
Table 1. Evaluation of some ideas describing modern e-government, according to the authors

\begin{tabular}{|c|c|c|c|c|c|c|c|}
\hline \multirow[b]{2}{*}{ \# } & \multirow[b]{2}{*}{$\begin{array}{l}\text { Some authors' ideas for } \\
\text { evaluation }\end{array}$} & \multicolumn{5}{|c|}{ Expert evaluation } & \multirow[t]{2}{*}{ Private expert opinion } \\
\hline & & 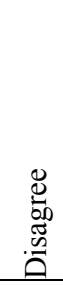 & 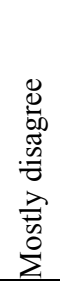 & $\begin{array}{l}\frac{2}{8} \\
\frac{\pi}{2} \\
\frac{8}{2} \\
\\
\end{array}$ & 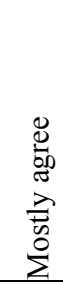 & 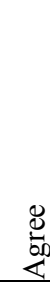 & \\
\hline 1 & $\begin{array}{l}\text { One of the main problems of the } \\
\text { e-government is the difficulty to } \\
\text { control the creation of new } \\
\text { technologies. }\end{array}$ & 3 & 1 & 3 & 5 & 3 & $\begin{array}{l}1 \text { expert: this is a question for } \\
\text { managers }\end{array}$ \\
\hline 2 & $\begin{array}{l}\text { There are two dominant digital } \\
\text { platforms in modern Russia: the } \\
\text { platform of the tax service and } \\
\text { the platform of Sberbank. }\end{array}$ & 2 & 6 & 1 & & 6 & $\begin{array}{l}1 \text { expert: quite a lot of more } \\
\text { successful digital platforms } \\
\text { are used in business } \\
2 \text { experts: }+ \text { public services, } \\
\text { public procurement }\end{array}$ \\
\hline 3 & $\begin{array}{l}\text { It seems that the digital } \\
\text { platforms dominating in modern } \\
\text { Russia will soon merge into a } \\
\text { single IT state corporation. }\end{array}$ & 1 & 1 & 2 & & 4 & $\begin{array}{l}1 \text { expert: the process is already } \\
\text { underway }\end{array}$ \\
\hline 4 & $\begin{array}{l}\text { The e-government will be less } \\
\text { bureaucratic, compared to the } \\
\text { traditional state. }\end{array}$ & 3 & 5 & 2 & 2 & 3 & $\begin{array}{l}1 \text { expert: a very serious } \\
\text { independent study is required } \\
\text { to find this out. } \\
1 \text { expert: it depends on the } \\
\text { meaning: procedures are } \\
\text { simplified, movements are } \\
\text { complicated }\end{array}$ \\
\hline 5 & $\begin{array}{l}\text { The e-government will be more } \\
\text { sociable, compared to the } \\
\text { traditional state }\end{array}$ & 3 & 3 & 1 & 5 & 3 & 1 expert: it will be faster. \\
\hline 6 & $\begin{array}{l}\text { The e-government will be more } \\
\text { open to society and citizens, } \\
\text { compared to the traditional state }\end{array}$ & 1 & 3 & 1 & 7 & 3 & $\begin{array}{l}1 \text { expert: it depends on those in } \\
\text { power }\end{array}$ \\
\hline 7 & $\begin{array}{l}\text { The e-government allows total } \\
\text { control over people. }\end{array}$ & 1 & 1 & & 5 & 8 & 1 expert: it is meant this way \\
\hline 8 & $\begin{array}{l}\text { Russia still lacks a systemic } \\
\text { regulatory framework required } \\
\text { for the successful formation of } \\
\text { the e-government. }\end{array}$ & & & 2 & 7 & 6 & \\
\hline 9 & $\begin{array}{l}\text { The e-government is based on } \\
\text { digital technology and artificial } \\
\text { intelligence. }\end{array}$ & 1 & 2 & & 3 & 9 & $\begin{array}{l}1 \text { expert: probably in an ideal } \\
\text { scenario, it is, but in practice, } \\
\text { this will not happen for a long } \\
\text { time in Russia. The e- } \\
\text { government will be managed } \\
\text { by the same officials as the } \\
\text { programs. } \\
1 \text { expert: this is commonplace. }\end{array}$ \\
\hline 10 & $\begin{array}{l}\text { The digital state is the core } \\
\text { element of the e-government. }\end{array}$ & 2 & & 1 & 8 & 4 & \\
\hline
\end{tabular}




\begin{tabular}{|l|l|l|l|l|l|l|l|}
\hline 11 & $\begin{array}{l}\text { The e-government threatens the } \\
\text { traditional values of Russian } \\
\text { society. }\end{array}$ & $\mathbf{1}$ & $\mathbf{3}$ & $\mathbf{1}$ & $\mathbf{6}$ & $\mathbf{4}$ & $\begin{array}{l}1 \text { expert: the "traditional } \\
\text { values" for Russian society are } \\
\text { unclear }\end{array}$ \\
\hline 12 & $\begin{array}{l}\text { The e-government promotes } \\
\text { rapprochement of peoples. }\end{array}$ & $\mathbf{4}$ & $\mathbf{3}$ & $\mathbf{3}$ & $\mathbf{4}$ & $\mathbf{1}$ & $\begin{array}{l}\text { 1 expert: the e-government is } \\
\text { not an end in itself, but just an } \\
\text { instrument. }\end{array}$ \\
\hline
\end{tabular}

Interpretation of the obtained results (they are calculated only horizontally, where "disagree" and "mostly disagree" have negative values, while "mostly agree" and "agree" have positive values. The number of "those undecided" is indicated separately and has a zero value).

Regarding the first idea. Most experts supported the authors' idea that "one of the main problems of the e-government was the difficulty to control the creation of new technologies": $+5+3-3-1=+4$, with three undecided experts. Indeed, this complexity should be taken into account when creating the e-government and when modernizing/modifying the domestic education system.

Regarding the second idea. The opinions were divided on the idea that "there were two dominant digital platforms in modern Russia: the platform of the tax service and the platform of Sberbank", although more experts disagreed with this idea: $+6-2-6=-2$, with one undecided. The experts noted in private comments that quite a lot of more successful digital platforms were used in business, and that public services and public procurement really existed.

Regarding the third idea. Most experts agreed that "the digital platforms dominating in modern Russia would soon merge into a single IT state corporation": $+7+4-1-1=+9$, with two undecided. One expert noted that such a process was already underway. Nevertheless, the authors of the article believe that such a scenario is not a foregone conclusion.

Regarding the fourth idea. Most experts did not agree that "the e-government would be less bureaucratic, compared to the traditional state": $+2+3-3-5=-3$, with two undecided. The experts noted in private comments that a very serious independent study was required to find this out, as well as that "procedures were simplified, and movements were complicated in the e-government." The authors of the article believe that the problem of bureaucratization or, vice versa, of the antibureaucratization of the e-government is indeed very ambiguous.

Regarding the fifth idea. A little more than half of the experts agreed that "the egovernment would be more sociable, compared to the traditional state": $+5+3-3-3=+2$, with one undecided. Most likely, they mean not verbal, but virtual communication through gadgets, social networks, the Internet, etc. in this case.

Regarding the sixth idea. Most experts agreed that "the e-government would be more open to society and citizens, compared to the traditional state": $+7+3-1-3=+6$, with one undecided. In this case, it must be noted that the information technology allows to "cover up" (that is, to reduce) the openness of the actions of the authorities for society and citizens, if necessary.

Regarding the seventh idea. The vast majority of the experts agreed that "the egovernment allowed total control over people": $+8+5-1-1=+11$. There is probably nothing to argue about (one expert noted: "it is meant this way"), the authors only emphasize that any state allows (!) for a total control over people and society.

Regarding the eighth idea. The vast majority of the experts agreed that "Russia still lacked a systemic regulatory framework required for the successful formation of the e-government": $+7+6=+13$, with two undecided. The authors can only agree with the opinion of the experts.

Regarding the ninth idea. The vast majority of the experts agreed that "the e-government was based on digital technology and artificial intelligence": $+3+9-1-2=+9$. The authors can only agree with the opinion of the experts. 
Regarding the tenth idea. The vast majority of the experts agreed that "the digital state was the core element of the e-government": $+8+4-2=+10$, with one abstaining. The authors of the article also agree with this opinion of the experts.

Regarding the eleventh idea. Most experts agreed that "the e-government threatened the traditional values of Russian society": $+6+4-1-3=+6$, with one undecided. Following one of the experts (who wanted to clarify the essence of traditional Russian values), the authors of the article believe that they do not include unpreparedness for changes in society, for modernization, and for reforms, as some politicians, experts and public figures say.

Regarding the twelfth idea. Not absolute, but still the majority of the experts did not agree that "the e-government promoted rapprochement of peoples": $+4+1-4-3=-2$, with three undecided. The authors of the article mostly agree that "the e-government is not an end in itself, but just an instrument" (as one expert noted). They also note that the rapprochement of peoples will be facilitated, first of all, by the same or similar values. If the advantages of the e-government become such a value, then it will certainly help bring nations closer together.

\section{Relationship between the obtained results and the education system}

How are the concept of the e-government and the Russian education system interconnected? Let us note a few points.

1. The authors believe that the information technology will increasingly penetrate the education system, thus virtualizing the relationship between the teachers and the students.

2. It seems that the market for information services will have increasing impact on the virtualization of the education system and may even form its own universities, as they say, tailored for its needs.

3. The line between the experts and the curious will blur in modern society, and people will continue to grow confidence in the futility of experts and expert knowledge [10, p. 20]. No respect for knowledge will be formed. Therefore, the authors insist that the DunningKruger and backfire effects will be increasingly relevant in modern society, as well as the Sturgeon's and Pommer's laws.

4. The constant conflict of facts and values, which caused at least a distrust of science in Western societies, will increasingly expand to Russia and the domestic education system.

5. As long as the Internet "kills" trust in society, the spread of the information technology in education will also reduce this trust.

6. As long as the Internet remains a great "balancer" in modern society, the relationship between the teacher and the students will become less vertical. The authors believe that the authority of teachers in Russian society will constantly decrease in the near future due to the information technology.

7. The authors believe that a common concept (or myth) of an innovative university will be tested for realism in the near future. This term is most likely acceptable in relation to technical universities (since fundamentally new products can be created in it [11, pp. $23-$ 24 ] - that is, it can be measured by entrepreneurial success), but how can the innovativeness of a humanitarian university be measured? Apparently, it can be measured by the degree of prevalence of the information technology.

\section{Conclusion}

The results of the authors' study devoted to the problems of the e-government development in Russia are presented in the article. Based on the expert survey, the conclusions have been 
drawn that the digitalization of education and public administration are closely related, but there are also some differences. The authors also want to emphasize the opinion that Russian university graduates will be less competitive than university graduates from countries with developed digital economies if modern realities in Russia are not taken into account and the IT technologies in the field of education and public administration are not developed.

\section{References}

1. A.A. Goryachev, S. A. Melkov, A. S. Sushansky, A. P. Shitova, A. V. Shubina, GosReg: gosudarstvennoye regulirovaniye obshchestvennykh otnosheniy 2, (2017).

Retrieved from: http://gosreg.amchs.ru/pdffiles/20number/articles/melkovshushanskiy-goryachev-shitova-shubina-20.pdf

2. V.Yu. Panchenko, R.A. Romashov, State and Law 7, 99-109 (2018)

3. A.F. Darmilov, M.B. Ponyavina, News of scientific achievements. Economics and Law 3, 82-85 (2020).

4. D.O. Giordano, M.B. Ponyavina, News of Scientific Achievements. Accounting, analysis and audit 2, 74-80 (2020)

5. V.H. Kremen, Ukrainian Educational Journal 3, 5-14 (2017)

6. Z. Huang, M. Semwal, W.S. Tan, R. Bajpai, W. Ong, S.Y. Lee, Tee M., L. Tudor Car, Journal of Medical Internet Research 21(2), (2019)

7. G. Weichhart, C. Stary, M. Appel, Knowledge Management and E-Learning 10(1), 2552 (2018)

8. X. Wang, Journal of Advanced Oxidation Technologies 21(2), (2018)

9. A. Hariharasudan, S. Kot, Social Sciences 7(11) 227, (2018).

10. T. Nichols, The Death of Expertise: How the Internet Kills Scientific Knowledge (Eksmo, Moscow, 2019)

11. M.V. Romm, R.A. Zayakina, Innovative university: a network perspective in partner communities: monograph (NTGU, Novosibirsk, 2018) 